\title{
Downregulation of P-gp, Ras and p-ERK1/2 contributes to the arsenic trioxide-induced reduction in drug resistance towards doxorubicin in gastric cancer cell lines
}

\author{
YUAN-YUAN ZHAO, LI YU, BAO-LING LIU, XIN-JIA HE and BI-YUAN ZHANG \\ Department of Oncology, The Affiliated Hospital of Medical College, \\ Qingdao University, Qingdao, Shandong 266000, P.R. China
}

Received July 15, 2014; Accepted June 5, 2015

DOI: $10.3892 / \mathrm{mmr} .2015 .4367$

\begin{abstract}
Multidrug resistance (MDR) to doxorubicin (DOX) limits its effectiveness against tumor cells. Arsenic trioxide $\left(\mathrm{As}_{2} \mathrm{O}_{3}\right)$ has been reported to reduce MDR in various types of cancer, but the mechanisms involving Ras and $\mathrm{p}$-glycoprotein (P-gp) remain to be fully elucidated. The objectives of the present study were to evaluate $\mathrm{As}_{2} \mathrm{O}_{3}$ in reversing MDR to DOX, and to identify the association in antitumor activities between the effectiveness of DOX and Ras/phosphorylated (p-) extracellular signal-regulated kinase (ERK)1/2 signaling in SGC7901/ADM and SGC7901/S human gastric cancer cell lines. Cytotoxicity and sensitivity towards $\mathrm{As}_{2} \mathrm{O}_{3}$ were assessed using non-toxic and mildly-toxic concentrations ( 0.1 and $0.5 \mu \mathrm{M}$, respectively). The reversing effect of $\mathrm{As}_{2} \mathrm{O}_{3}$ on MDR was investigated prior to and following treatment with a cytokine activation of the recombinant human granulocyte colony stimulating factor ERK pathway. The SGC7901/ADM and SGC7901/S cells had the same sensitivity to $\mathrm{As}_{2} \mathrm{O}_{3}$. The SGC7901/ADM cells were resistant to DOX and $\mathrm{As}_{2} \mathrm{O}_{3}$ treatment reduced the level of resistance to DOX $(\mathrm{P}<0.01)$. The expression of $\mathrm{P}$-glycoprotein $(\mathrm{P}-\mathrm{gp})$ in the SGC7901/ADM cells was higher than in the SGC7901/S cells $(\mathrm{P}<0.001) . \mathrm{As}_{2} \mathrm{O}_{3}$ treatment decreased the levels of $\mathrm{P}$-gp in a time- and dose-dependent manner $(\mathrm{P}<0.01)$. The expression of Ras was higher in the SGC7901/ADM cells than in the SGC7901/S cells, while the expression of p-ERK1/2 remained the same. $\mathrm{As}_{2} \mathrm{O}_{3}$ decreased the levels of Ras and p-ERK1/2 $(\mathrm{P}<0.01)$. Following pretreatment with $\mathrm{rhG}-\mathrm{CSF}$, the levels of Ras and p-ERK1/2 were further decreased $(\mathrm{P}<0.01)$. Drug-resistant gastric cancer cells had higher expression levels
\end{abstract}

Correspondence to: Dr Yuan-Yuan Zhao, Department of Oncology, The Affiliated Hospital of Medical College, 16 Jiangsu Road, Qingdao University, Qingdao, Shandong 266000, P.R. China E-mail: zhaoyuanyuanmedsci@163.com

Key words: arsenic trioxide, extracellular signal-regulated mitogen-activated protein kinases, Ras, P-Glycoprotein, gastric cancer, multidrug resistance, doxorubicin of P-gp and Ras, but not of p-ERK1/2. Non- and mildly-toxic doses of $\mathrm{As}_{2} \mathrm{O}_{3}$ reduced MDR to DOX through Ras/p-ERK1/2 signaling.

\section{Introduction}

In 2008, there were a 989,600 new cases of gastric cancer (GC) and a GC-associated mortality rate of 738,000 worldwide (1). Although the rate of GC-associated mortality has declined in the last 50 years (2), it remains the second leading cause of cancer-associated mortality worldwide, with an incidence rate ranking fourth following lung, breast and colorectal cancer (3). Systemic chemotherapy remains critical in the treatment of GC.

DOX is a well-known chemotherapeutic treatment used in Hodgkin's lymphoma, non-Hodgkin's lymphoma, multiple myeloma, acute leukemia, Kaposi's sarcoma, Ewing's sarcoma, Wilms' tumor and in solid tumors of the breast, adrenal cortex, prostate, thyroid, head and neck, endometrium, lung and ovary (4). DOX is widely used to treat GC in combination regimens with etoposide, cisplatin and 5-fluorouracil. However, drug resistance to DOX significantly limits its efficacy. Resistance to DOX is often associated with the expression of p-glycoprotein (P-gp) (4).

Multidrug resistance (MDR) is a complex process due to several mechanisms. Numerous resistance-associated proteins, including P-gp, have been found in different cancer cells, and overexpression of this transmembrane glycoprotein causes accelerated efflux of several lipid-soluble chemotherapeutic agents from the cells, decreasing their efficacy and leading to treatment failure (5). The difficulty of reversing this mechanism underlies its complexity.

Arsenic trioxide $\left(\mathrm{As}_{2} \mathrm{O}_{3}\right)$ appears to achieve complete remission in $70 \%$ of patients with acute promyelocytic leukemia (APL) by inducing cancer cell apoptosis (6). Additional studies have confirmed that low doses of $\mathrm{As}_{2} \mathrm{O}_{3}$ induces complete remission in $90 \%$ of relapsed patients with APL (7-9). To date, a number of studies have provided novel insights into the pathogenesis of this agent and indicate that $\mathrm{As}_{2} \mathrm{O}_{3}$ may be useful in treating other types of cancer $(10,11)$. It has become evident that the effects of $\mathrm{As}_{2} \mathrm{O}_{3}$ are not restricted to APL cells, but that $\mathrm{As}_{2} \mathrm{O}_{3}$ may also be effective in other malignant cells in 
several of types of cancer, including chronic myeloid leukemia, multiple myeloma, and solid prostate, esophageal and ovarian tumors (12-15). A number of mechanisms are associated with the effects of $\mathrm{As}_{2} \mathrm{O}_{3}$, including the induction of apoptosis, inhibition of growth, inhibition of differentiation and angiogenesis, and inhibition of mitochondrial respiration (16-18). In addition, several signaling pathways are involved in the antitumoral activity of $\mathrm{As}_{2} \mathrm{O}_{3}$, including inactivation of the Notch, c-Jun NH2-terminal kinase (JNK) and extracellular signal-regulated kinase (ERK) signaling pathways (19-21). Human GC cells have been found to be sensitive to $\mathrm{As}_{2} \mathrm{O}_{3}(22)$.

Few studies have investigated the involvement of Ras and $\mathrm{P}-\mathrm{gp}$ in MDR in GC cancer. The present study was designed to assess $\mathrm{As}_{2} \mathrm{O}_{3}$ in reversing DIX-induced MDR in GC cancer cell lines. The association between the antitumor effects of $\mathrm{As}_{2} \mathrm{O}_{3}$ and the Ras/phosphorylated (p-)ERK1/2 signaling pathway was also examined. The results of the present study aimed to provide novel insights into the treatment of gastric cancer.

\section{Materials and methods}

Chemicals and reagents. In the present study, $\mathrm{As}_{2} \mathrm{O}_{3}$ and 3-(4, 5-Dimethylthiazol-2-yl)-2, 5-diphenyltetrazolium bromide (MTT) were purchased from Sigma-Aldrich (St. Louis, MO, USA). Cyclosporin A (CsA) was purchased from Novartis (Bale, Switzerland). RPMI 1640, fetal bovine serum (FBS), and dimethyl sulfoxide (DMSO) were purchased from Thermo Fisher Scientific (Hyclone, Waltham, MA, USA). DOX was purchased from Zhejiang Haizheng Pharmaceutical Co. (Taizhou, China). The recombinant human granulocyte colony stimulating factor (rhG-CSF) was purchased from Qilu Pharmaceutical (Jinan, China). The mouse anti-P-gp (P-170), Ras (cat. no. ZA-0343), p-ERK1/2 (cat. no. sc-7383), horseradish peroxidase (HRP)-conjugated goat-anti-mouse secondary antibody and the corresponding immunohistochemistry kits were purchased from Beijing Golden Bridge Biotechnology Co. (Beijing, China).

Cell culture. The parental SGC7901/S human GC cell line and the DOX-resistant SGC7901/ADM cell line were obtained from the Key Laboratory of Cancer Biology and Xijing Hospital of Digestive Diseases, Fourth Military Medical University (Xi'an, China). The SGC7901/ADM cells were obtained from the SGC7901/S cells, based on a previously described method (23). In brief, the SGC7901/ADM cells were induced in vitro by continuous exposure of SGC7901 parent cells to adriamycin (ADM) at concentrations of $0.25 \mu \mathrm{g} / 1$ to $25 \mu \mathrm{g} / \mathrm{l}$. Cell lines capable of sustained growth in medium containing $25 \mu \mathrm{g} / 1 \mathrm{ADM}$ were considered to be resistant after 3 months. The SGC7901/S cells were cultured in RPMI 1640 medium supplemented with $100 \mathrm{U} / \mathrm{ml}$ penicillin, $100 \mu \mathrm{g} / \mathrm{ml}$ streptomycin and $10 \%$ (v/v) heat-inactivated FBS. The SGC7901/ADM cells were cultured in the same medium with $1 \mu \mathrm{g} / \mathrm{ml} \mathrm{DOX}$, and were grown without DOX for 2 weeks prior to the experiments. All the cells were cultured at $37^{\circ} \mathrm{C}$ in a $5 \% \mathrm{CO}_{2}$ humidified atmosphere and analyses were performed in the logarithmic growth phase.

Cytotoxicity and sensitivity of SGC7901/S and SGC7901/ADM cells to $\mathrm{As}_{2} \mathrm{O}_{3}$. The SGC7901/S and SGC7901/ADM cells were trypsinized, centrifuged at $1,000 \mathrm{x} \mathrm{g}$ for $5 \mathrm{~min}$, harvested and seeded into 96 -well plates, in triplicate, at a density of $1 \times 10^{4}$ cells/well $(100 \mu \mathrm{l})$ at $37^{\circ} \mathrm{C}$. Following overnight incubation, the cells became adherent. The culture medium was removed and $\mathrm{As}_{2} \mathrm{O}_{3}$ was added at 12 concentrations $(0.01,0.05$, $0.10,0.25,0.50,0.75,1.0,2.5,5.0,10.0,15.0$ or $20.0 \mathrm{mM})$. The cells $\left(1 \times 10^{4}\right.$ cells/well) were incubated for $24 \mathrm{~h}, 48 \mathrm{~h}$ and $72 \mathrm{~h}$, and were further incubated for an additional $4 \mathrm{~h}$ in the presence of $10 \mu \mathrm{l} /$ well of MTT reagent, containing $5.00 \mathrm{mg} / \mathrm{ml}$ in phosphate-buffered saline (PBS). Following aspiration of the medium, the resulting formazan was dissolved with DMSO (100 $\mu \mathrm{l} / \mathrm{cell})$. The plates were agitated mechanically for $60 \mathrm{sec}$, and the optical density (OD) or absorbance was measured immediately at $490 \mathrm{~nm}$ on a microplate reader (AR2010; Bio-Rad Laboratories, Inc., Hercules, CA, USA). The cell survival rate was calculated as: (OD of the assessment group / OD of the control group) $\mathrm{x} 100 \%$. The inhibition rate and half maximal inhibitory concentration of the reagent $\left(\mathrm{IC}_{50}\right)$ were calculated based on the survival rate (SR) $(24,25)$. The dose of $\mathrm{As}_{2} \mathrm{O}_{3}$, which resulted in a SR of $>95 \%$ was considered non-toxic, and the dose resulting in a SR $>85 \%$ was considered mildly-toxic.

Resistance of SGC7901/ADM cells and the resistance-reversing effect of $\mathrm{As}_{2} \mathrm{O}_{3}$. The present study included five groups, which were as follows: SGC7901/ADM, SGC7901/S, $\mathrm{SGC7901/ADM+As} \mathrm{O}_{3}(0.10 \mu \mathrm{M}), \mathrm{SGC7901/ADM}+\mathrm{As}_{2} \mathrm{O}_{3}$ $(0.50 \mu \mathrm{M})$ and SGC7901/ADM+CsA $(4.00 \mu \mathrm{g} / \mathrm{ml})$. These two concentrations of $\mathrm{As}_{2} \mathrm{O}_{3}$ were selected as the non-toxic and the mildly-toxic doses in the experiment described above. To investigate the drug resistance-reversing effect of $\mathrm{As}_{2} \mathrm{O}_{3}$, DOX $(0.1,0.5,1.0,2.5,5.0,10.0,15.0$ and $30.0 \mu \mathrm{g} / \mathrm{ml})$ was added to the cell culture $\left(1 \times 10^{4}\right.$ cells/well), rather than $\mathrm{As}_{2} \mathrm{O}_{3}$. The cells were then incubated for $24 \mathrm{~h}$ and $48 \mathrm{~h}$ at $37^{\circ} \mathrm{C}$. The drug resistance ratio was calculated as the $\mathrm{IC}_{50}$ of the drug-resistant cells divided by the $\mathrm{IC}_{50}$ of the parental cells. The reversal ratio was calculated as the $\mathrm{IC}_{50}$ of the drug-resistant cells divided by the $\mathrm{IC}_{50}$ of the drug-resistant cells treated with reversal agents,

Reversing effect of $\mathrm{As}_{2} \mathrm{O}_{3}$ following treatment with rhG-CSF. The SGC7901/ADM, SGC7901/S,

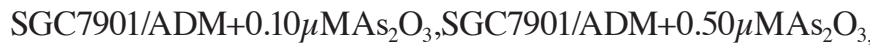
and SGC7901/ADM+4.00 $\mu \mathrm{g} / \mathrm{ml} \mathrm{CsA}$ cells $\left(1 \times 10^{4}\right.$ cells/well) were incubated with rhG-CSF $(1.50 \mu \mathrm{g} / \mathrm{ml})$ for 3 days at $37^{\circ} \mathrm{C}$, and then cultured with DOX at different concentrations $(0.1$, $0.5,1.0,2.5,5.0,10.0,30.0,40.0$ and $50.0 \mu \mathrm{M}$ ) for a further 2 days at $37^{\circ} \mathrm{C}$, following which the reversing effect of $\mathrm{As}_{2} \mathrm{O}_{3}$ was assessed. The blank control contained no cells in the culture medium, while the negative control contained medium with no reagent.

Analyzing the expression of P-gp using western blotting. The SGC7901/ADM and SGC7901/S cells (1x10 4 cells/well) were grouped, as described above, and were pretreated with non- and mildly-toxic concentrations of $\mathrm{As}_{2} \mathrm{O}_{3}$ for 24, 48 and $72 \mathrm{~h}$ (18). The cells were collected by centrifugation at $1,000 \mathrm{x} \mathrm{g}$ for $20 \mathrm{~min}$ at $4^{\circ} \mathrm{C}$ and washed with ice-cold PBS. The cell pellets were then resuspended in lysis buffer (Invitrogen Life Technologies, Carlsbad, CA, USA), containing $50 \mathrm{mM}$ Tris-chloride ( $\mathrm{pH} 7.4), 150 \mathrm{mM}$ sodium chloride, $0.1 \%$ sodium dodecyl sulfate, $1 \%$ Triton-100 and $1 \mathrm{mM}$ ethyl- 
enediaminetetraacetic acid ( $\mathrm{pH}$ 8.0). Following incubation at $4^{\circ} \mathrm{C}$ for $40 \mathrm{~min}$, the samples were centrifuged at $15,400 \mathrm{x} \mathrm{g}$ for $20 \mathrm{~min}$. The supernatants containing cytosolic proteins were separated by polyacrylamide gel (Bio-Rad Laboratories, Inc.) electrophoresis at $200 \mathrm{~V}$ for $1-2 \mathrm{~h}$, and were transferred onto a nitrocellulose membrane (EMD Millipore, Billerica, MA, USA) at $120 \mathrm{~V}$ for $3 \mathrm{~h}$. The membrane was blocked with $5 \%$ skim milk powder at room temperature for $2 \mathrm{~h}$, followed by incubation with primary monoclonal mouse anti-human antibody (P-gp, 1:50) for $2 \mathrm{~h}$ at room temperature. Following washing with blocking buffer, the membranes were incubated with HRP-conjugated goat-anti-mouse secondary antibody $(1: 1,000)$ for $2 \mathrm{~h}$ at room temperature, followed by chemiluminescence detection (Pierce Biotechnology, Inc., Rockford, IL, USA). Western blot analysis was performed using an image analysis system (VIDAS System; Biomérieux, Marcy l'Étoile, France).

\section{Immunocytochemical assays}

Expression levels of Ras and p-ERK1/2 in cells treated with $\mathrm{As}_{2} \mathrm{O}_{3}$. A total of six treatment groups were used to assess the levels of Ras and p-ERK1/2: SGC7901/ADM+As $\mathrm{O}_{3}$ $(0.10,0.50$, and $0.75 \mu \mathrm{M})$, SGC7901/ADM+CsA $(4.00 \mu \mathrm{g} / \mathrm{ml})$, SGC7901/ADM and SGC7901/S. The cells (1x10 4 cells/well) were treated, as described above, and incubated for 24, 48, and $72 \mathrm{~h}$. As previously described (13), the cells were fixed in ice-cold acetone for $15 \mathrm{~min}$. Following incubating with $3 \%$ hydrogen peroxide-carbinol for $10 \mathrm{~min}$, the cells were incubated at $37^{\circ} \mathrm{C}$ for $2 \mathrm{~h}$ with the following primary antibodies: Mouse-anti-human monoclonal Ras or p-ERK1/2. Following incubation with Poly Helper (50 $\mu$; Santa Cruz Biotechnology, Inc., Santa Cruz, CA, USA) at $37^{\circ} \mathrm{C}$ for $30 \mathrm{~min}$, the HRP-conjugated goat-anti-mouse IgG antibody solution was added and incubated again at $37^{\circ} \mathrm{C}$ for $30 \mathrm{~min}$. Finally, staining with 3,3'-diaminobenzidine (Sigma-Aldrich) and hematoxylin (Sigma-Aldrich) were performed. The labeled cells were analyzed using an image analysis system (VIDAS, Option Company).

Expression levels of Ras and p-ERK1/2 following treatment with an ERK activator. rhG-CSF is a cytokine, which activates a number of cellular pathways, including the ERK pathway (26,27). Therefore, the SGC7901/ADM and SGC7901/S cells $\left(1 \times 10^{4}\right.$ cells/well) were treated with $\mathrm{rhG-CSF}$ $(1.50 \mu \mathrm{g} / \mathrm{ml})$ for 3 days at $37^{\circ} \mathrm{C}$, and then divided into the five treatment groups, described above. The cells were then incubated with the primary antibody. The experiments were repeated three times.

Statistical analysis. Data are presented as the mean \pm standard deviation of three independent experiments. Student's t-test and analysis of variance were used to analyze the differences between groups, with a Student-Newman-Keuls (q-test) post hoc test. $\mathrm{P}<0.05$ was considered to indicate a statistically significant difference. All data were analyzed using SPSS 17.0 (SPSS Inc., Chicago, IL, USA).

\section{Results}

Sensitivity of SGC7901/ADM and SGC7901/S cells to $\mathrm{As}_{2} \mathrm{O}_{3}$. In the present study, SGC7901/ADM and SGC7901/S cells were treated with different concentrations of $\mathrm{As}_{2} \mathrm{O}_{3}$ for 24, 48 and $72 \mathrm{~h}$, following which the OD at $490 \mathrm{~nm}$ was measured and the $\mathrm{IC}_{50}$ and survival rates were calculated (Table I). The $\mathrm{IC}_{50}$ values of the two cell types to $\mathrm{As}_{2} \mathrm{O}_{3}$ decreased gradually with increasing treatment duration. However, no difference was observed between the two cell lines at any time-point (all $\mathrm{P}>0.05$ ). Doses of 0.1 and $0.5 \mathrm{mM}$ were considered non-toxic and mildly-toxic doses, respectively (Table I), and subsequent experiments were performed using these doses. These results revealed that the SGC7901/ADM and SGC7901/S cells had the same sensitivity to $\mathrm{As}_{2} \mathrm{O}_{3}$, which occurred in a time- and dose-dependent manner.

$\mathrm{As}_{2} \mathrm{O}_{3}$ reduces drug resistance of $S G C 7901 / A D M$ cells to DOX, possibly through the p-ERK1/2 pathway. The $\mathrm{IC}_{50}$ to DOX was assessed in the five groups of cells incubated for 24 and $48 \mathrm{~h}$. The experimental groups were: SGC7901/ADM+0.10 $\mu \mathrm{M} \mathrm{As}_{2} \mathrm{O}_{3}$ and SGC7901/ADM+0.50 $\mu \mathrm{M} \mathrm{As}_{2} \mathrm{O}_{3}$. The positive control group was SGC7901/ADM+4.00 $\mu \mathrm{g} / \mathrm{ml}$ CsA. The negative control groups were SGC7901/ADM and SGC7901/S. The results revealed that the level of drug resistance between the resistant and parental cells were 6.63- and 6.85-fold at $24 \mathrm{~h}$ and $48 \mathrm{~h}$, respectively (Table II). The $\mathrm{IC}_{50}$ values to DOX in the experimental groups were significantly lower than that in the SGC7901/ADM group when treated with $0.10 \mu \mathrm{M}$ at 24 and $48 \mathrm{~h}(\mathrm{P}<0.01)$ and with $0.50 \mu \mathrm{M}$ at 24 and $48 \mathrm{~h}(\mathrm{P}<0.01)$. The reversal in the CsA group was $\sim 4.5$-fold at different time points, while in the experimental groups, the effect was time-dependent (Table II). The $\mathrm{IC}_{50}$ of $\mathrm{As}_{2} \mathrm{O}_{3}$ at $0.50 \mu \mathrm{M}$ was markedly lower than that at $\mathrm{As}_{2} \mathrm{O}_{3}$ at $0.10 \mu \mathrm{M}$, particularly at $48 \mathrm{~h}$. The value was close to that in the SGC7901/S group and lower than that in the CsA group, but without statistical significance $(\mathrm{P}>0.05)$.

Following treatment with rhG-CSF, a cytokine that activates the ERK pathway, the $\mathrm{IC}_{50}$ at $48 \mathrm{~h}$ was assessed again (Table II). Compared with the cells without rhG-CSF treatment, the $\mathrm{IC}_{50}$ to DOX of $\mathrm{As}_{2} \mathrm{O}_{3}(0.50 \mu \mathrm{M})$ was significantly higher $(\mathrm{P}<0.05)$, suggesting that the ERK activator had the ability to partially reduce the drug resistance-reversing effect of $\mathrm{As}_{2} \mathrm{O}_{3}$.

These findings suggested that the SGC7901/ADM cells were resistant to $\mathrm{DOX}$, and that $\mathrm{As}_{2} \mathrm{O}_{3}$ had a drug resistance-reversing effect, in a time- and dose-dependent manner. In addition, p-ERK1/2 may be involved in this mechanism, which requires further investigation.

Reduction in the expression of P-gp. The expression of P-gp was detected using western blotting (Fig. 1). The expression of P-gp was more marked in the SGC7901/ADM cells than in the SGC7901/S cells $(0.38 \pm 0.025$ vs. $0.19 \pm 0.012$, respectively; $\mathrm{P}<0.001$ ), without significant variation in with time (Table III). In the SGC7901/ADM cells, $\mathrm{As}_{2} \mathrm{O}_{3}$ at the non-toxic concentration $(0.10 \mu \mathrm{M})$ at $24 \mathrm{~h}$ did not decrease the protein expression of $\mathrm{P}-\mathrm{gp}$, however, the increase in duration significantly decreased the levels of $\mathrm{P}-\mathrm{gp}(\mathrm{P}<0.01)$. Unlike the non-toxic concentration, the mildly-toxic concentration $(0.50 \mu \mathrm{M})$ reduced the levels of $\mathrm{P}$-gp even at $24 \mathrm{~h}(\mathrm{P}<0.01)$. In the positive control cells, the levels of P-gp were close to that in the SGC7901/S cells, without significant changes with time (Table III). These results revealed that the expression of P-gp in the drug-resistant cells was higher than in the parental cells. CsA appeared to reduce the protein expression of $\mathrm{P}$-gp, and $\mathrm{As}_{2} \mathrm{O}_{3}$ decreased the levels 
Table I. $\mathrm{IC}_{50}$ volume of non- and mildly-toxic doses of arsenic trioxide at different time-points.

\begin{tabular}{|c|c|c|c|c|c|c|c|c|c|}
\hline \multirow[b]{2}{*}{ Cell line } & \multicolumn{3}{|c|}{$\mathrm{IC}_{50} \mu \mathrm{M}^{\mathrm{a}}$} & \multicolumn{3}{|c|}{$95 \%>\mathrm{SR}>85 \%^{\mathrm{b}}$} & \multicolumn{3}{|c|}{$\mathrm{SR}>95 \%^{\mathrm{c}}$} \\
\hline & $24 \mathrm{~h}$ & $48 \mathrm{~h}$ & $72 \mathrm{~h}$ & $24 \mathrm{~h}$ & $48 \mathrm{~h}$ & $72 \mathrm{~h}$ & $24 \mathrm{~h}$ & $48 \mathrm{~h}$ & $72 \mathrm{~h}$ \\
\hline SGC7901/ADM & $5.57 \pm 0.36$ & $2.63 \pm 0.18$ & $1.42 \pm 0.09$ & $0.10-0.08$ & $0.10-0.75$ & $0.05-0.25$ & $0.01-0.01$ & $0.01-0.01$ & $0.01-0.05$ \\
\hline SGC7901/S & $5.94 \pm 0.54$ & $3.06 \pm 0.28$ & $1.59 \pm 0.12$ & $0.25-1.30$ & $0.07-0.08$ & $0.04-0.25$ & $0.01-0.25$ & $0.01-0.07$ & $0.01-0.04$ \\
\hline
\end{tabular}

${ }^{a}$ Data are presented as the mean \pm standard deviation of three experiments $(\mathrm{n}=3) ;{ }^{\mathrm{b}} \mathrm{SR}>95 \%$ was considered the non-toxic dose; ${ }^{\mathrm{c}} 95 \%>\mathrm{SR}>85 \%$ was considered a mildly-toxic dose. $\mathrm{SR}$, survival rate; $\mathrm{IC}_{50}$, half maximal inhibitory concentration.

Table II. Comparison of the $\mathrm{IC}_{50}$ values of DOX and drug-reversing ratio of $\mathrm{As}_{2} \mathrm{O}_{3}$ at different time-points.

\begin{tabular}{|c|c|c|c|c|}
\hline \multirow[b]{2}{*}{ Factor } & \multirow[b]{2}{*}{ Treatment } & \multicolumn{2}{|c|}{-rhG-CSF } & \multirow{2}{*}{$\frac{+ \text { rhG-CSF }}{48 \mathrm{~h}}$} \\
\hline & & $24 \mathrm{~h}$ & $48 \mathrm{~h}$ & \\
\hline \multirow[t]{5}{*}{$\mathrm{IC}_{50}$ to $\mathrm{DOX}^{\mathrm{a}}$} & $\mathrm{As}_{2} \mathrm{O}_{3}(0.1 \mu \mathrm{M})$ & $23.46 \pm 3.30$ & $14.35 \pm 1.84$ & $19.28 \pm 2.16$ \\
\hline & $\mathrm{As}_{2} \mathrm{O}_{3}(0.5 \mu \mathrm{M})$ & $9.52 \pm 1.02$ & $4.28 \pm 0.55$ & $6.85 \pm 1.31$ \\
\hline & $\mathrm{CsA}(4 \mu \mathrm{g} / \mathrm{ml})$ & $7.62 \pm 0.83$ & $5.98 \pm 0.71$ & $7.73 \pm 2.24$ \\
\hline & SGC7901/ADM & $34.31 \pm 4.38$ & $26.94 \pm 3.67$ & $32.39 \pm 4.52$ \\
\hline & SGC7901/S & $5.17 \pm 0.46$ & $3.93 \pm 0.42$ & $5.49 \pm 0.68$ \\
\hline Drug-resistance ratio ${ }^{\mathrm{b}}$ & & 6.63 & 6.85 & 5.90 \\
\hline \multirow[t]{3}{*}{ Drug-reversal ratio ${ }^{c}$} & $\mathrm{As}_{2} \mathrm{O}_{3}(0.1 \mu \mathrm{M})$ & 1.46 & 1.87 & 1.68 \\
\hline & $\mathrm{As}_{2} \mathrm{O}_{3}(0.5 \mu \mathrm{M})$ & 3.60 & 6.29 & 4.72 \\
\hline & $\mathrm{CsA}(4 \mu \mathrm{g} / \mathrm{ml})$ & 4.50 & 4.51 & 4.19 \\
\hline
\end{tabular}

${ }^{a}$ Data are presented as the mean \pm standard deviation. ${ }^{b}$ Drug resistance ratio was calculated as the $\mathrm{IC}_{50}$ of resistant cells to that of SGC7901/S cells. ${ }^{~}$ Reversal ratio was calculated as the $\mathrm{IC}_{50}$ of resistant cells to the reversal-agent treated cells. $\mathrm{As}_{2} \mathrm{O}_{3}$, arsenic trioxide; CsA, cyclosporin $\mathrm{A}$; $\mathrm{IC}_{50}$, half maximal inhibitory concentration; DOX, doxorubicin; rhG-CSF, recombinant human granulocyte colony stimulating factor.

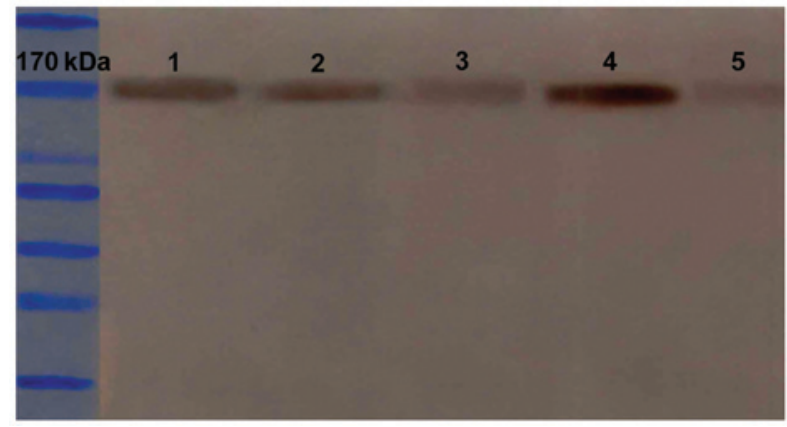

Figure 1. Protein expression levels of P-gp with or without arsenic trioxide treatment for $48 \mathrm{~h}$, determined using western blotting. 1, protein expression of P-gp in SGC7901/ADM cells treated with $0.1 \mu \mathrm{M} \mathrm{As}_{2} \mathrm{O}_{3}$ for $48 \mathrm{~h}$; 2, protein expression of P-gp in SGC7901/ADM cells treated with $0.5 \mu \mathrm{M} \mathrm{As}_{2} \mathrm{O}_{3}$ for $48 \mathrm{~h}$; 3, protein expression of P-gp in SGC7901/ADM cells treated with $4 \mathrm{~g} / \mathrm{ml} \mathrm{CsA}$ for $48 \mathrm{~h}$; 4, protein expression of P-gp in SGC7901/ADM cells without $\mathrm{As}_{2} \mathrm{O}_{3} ; 5$, protein expression of P-gp in SGC7901/S without $\mathrm{As}_{2} \mathrm{O}_{3}$. P-gp, p-glycoprotein; CsA, cyclosporin $\mathrm{A} ; \mathrm{As}_{2} \mathrm{O}_{3}$, arsenic trioxide.

of P-gp, even at non- or mildly-toxic concentrations, in a timeand dose-dependent manner.

Expression of Ras and p-ERK1/2 expression, determined using immunocytochemistry. Ras protein was predominantly localized in the membrane and partially translocated in the cytoplasm close to the membrane (Fig. 2A). The expression of Ras was higher in the SGC7901/ADM cells than in the SGC7901/S cells $(\mathrm{P}<0.01)$. Following treatment with $\mathrm{As}_{2} \mathrm{O}_{3}$, the levels of Ras were reduced in a time- and dose-dependent manner (Table III; Fig. 2B). At $24 \mathrm{~h}$, only the $0.75 \mu \mathrm{M}$ group exhibited lower expression than the SGC7901/ADM cells $(\mathrm{P}<0.01)$. At 48 and $72 \mathrm{~h}$, the cell groups treated with $\mathrm{As}_{2} \mathrm{O}_{3}$ had significantly lower levels of $\operatorname{Ras}(\mathrm{P}<0.05)$. The expression of Ras in the three control groups remained stable over time. These results suggested that drug-resistant cells may have a higher expression levels of Ras expression, and that $\mathrm{As}_{2} \mathrm{O}_{3}$ decreases these levels.

Expression of p-ERK1/2 expression was detected in the cytoplasm surrounding the nucleus of cells (Fig. 3A and B). No significant differences were identified in the levels of p-ERK1/2 between the SGC7901/ADM, SGC7901/S and CsA-treated cells. Following treatment with $\mathrm{As}_{2} \mathrm{O}_{3}$, the protein expression of p-ERK1/2 decreased (Table III). At $24 \mathrm{~h}$, the levels of $\mathrm{p}$-ERK1/2 were decreased at all $\mathrm{As}_{2} \mathrm{O}_{3}$ concentrations, without statistical significance $(\mathrm{P}>0.05)$. However, in the 0.50 and $0.75 \mu \mathrm{M} \mathrm{As}_{2} \mathrm{O}_{3}$ groups, the expression of $\mathrm{p}$-ERK1/2 was decreased, particularly in the $\mathrm{As}_{2} \mathrm{O}_{3} 0.75 \mu \mathrm{M}$ group at $72 \mathrm{~h}$ $(\mathrm{P}<0.01)$. These results suggested that the Ras/p-ERK1/2 signaling pathway may be involved in the mechanism of reducing drug resistance to DOX by $\mathrm{As}_{2} \mathrm{O}_{3}$ in GC cells. 
Table III. Comparison of the OD values of P-gp, measured using western blot analysis, and the expression levels of Ras and p-ERK1/2, measured using immunocytochemistry, at different time-points.

\begin{tabular}{|c|c|c|c|c|}
\hline \multirow[b]{2}{*}{ Protein } & \multirow[b]{2}{*}{ Treatment } & \multicolumn{3}{|c|}{ OD value } \\
\hline & & $24 \mathrm{~h}$ & $48 \mathrm{~h}$ & $72 \mathrm{~h}$ \\
\hline \multirow[t]{5}{*}{ P-gp } & $\mathrm{As}_{2} \mathrm{O}_{3}(0.1 \mu \mathrm{M})$ & $0.349 \pm 0.001$ & $0.32 \pm 0.003$ & $0.29 \pm 0.002$ \\
\hline & $\mathrm{As}_{2} \mathrm{O}_{3}(0.5 \mu \mathrm{M})$ & $0.30 \pm 0.002$ & $0.28 \pm 0.002$ & $0.16 \pm 0.001$ \\
\hline & $\mathrm{CsA}(4 \mu \mathrm{g} / \mathrm{ml})$ & $0.16 \pm 0.004$ & $0.16 \pm 0.001$ & $0.15 \pm 0.002$ \\
\hline & SGC7901/ADM & $0.32 \pm 0.061$ & $0.38 \pm 0.010$ & $0.38 \pm 0.005$ \\
\hline & SGC7901/S & $0.14 \pm 0.003$ & $0.14 \pm 0.003$ & $0.14 \pm 0.002$ \\
\hline \multirow[t]{6}{*}{ Ras } & $\mathrm{As}_{2} \mathrm{O}_{3}(0.1 \mu \mathrm{M})$ & $0.091 \pm 0.004$ & $0.084 \pm 0.001$ & $0.080 \pm 0.002$ \\
\hline & $\mathrm{As}_{2} \mathrm{O}_{3}(0.5 \mu \mathrm{M})$ & $0.089 \pm 0.003$ & $0.078 \pm 0.003$ & $0.076 \pm 0.003$ \\
\hline & $\mathrm{As}_{2} \mathrm{O}_{3}(0.75 \mu \mathrm{M})$ & $0.081 \pm 0.004$ & $0.073 \pm 0.002$ & $0.073 \pm 0.002$ \\
\hline & $\mathrm{CsA}(4 \mu \mathrm{g} / \mathrm{ml})$ & $0.091 \pm 0.003$ & $0.093 \pm 0.003$ & $0.084 \pm 0.005$ \\
\hline & SGC7901/ADM & $0.093 \pm 0.003$ & $0.090 \pm 0.003$ & $0.091 \pm 0.004$ \\
\hline & SGC7901/S & $0.068 \pm 0.003$ & $0.071 \pm 0.005$ & $0.066 \pm 0.008$ \\
\hline \multirow[t]{6}{*}{ p-ERK1/2 } & As2O3 $(0.1 \mu \mathrm{M})$ & $0.099 \pm 0.009$ & $0.086 \pm 0.002$ & $0.083 \pm 0.004$ \\
\hline & $\mathrm{As}_{2} \mathrm{O}_{3}(0.5 \mu \mathrm{M})$ & $0.086 \pm 0.007$ & $0.080 \pm 0.002$ & $0.070 \pm 0.001$ \\
\hline & $\mathrm{As}_{2} \mathrm{O}_{3}(0.75 \mu \mathrm{M})$ & $0.08 \pm 0.004$ & $0.078 \pm 0.005$ & $0.067 \pm 0.002$ \\
\hline & $\mathrm{CsA}(4 \mu \mathrm{g} / \mathrm{ml})$ & $0.098 \pm 0.009$ & $0.11 \pm 0.018$ & $0.11 \pm 0.025$ \\
\hline & SGC7901/ADM & $0.11 \pm 0.008$ & $0.11 \pm 0.012$ & $0.11 \pm 0.014$ \\
\hline & SGC7901/S & $0.10 \pm 0.016$ & $0.090 \pm 0.010$ & $0.10 \pm 0.027$ \\
\hline
\end{tabular}

Data are presented as the mean \pm standard deviation of three experiments. $\mathrm{As}_{2} \mathrm{O}_{3}$, arsenic trioxide; CsA, cyclosporin A; P-gp, P-glycoprotein; p-ERK, phosphorylated extracellular signal-regulated kinase; OD, optical density.
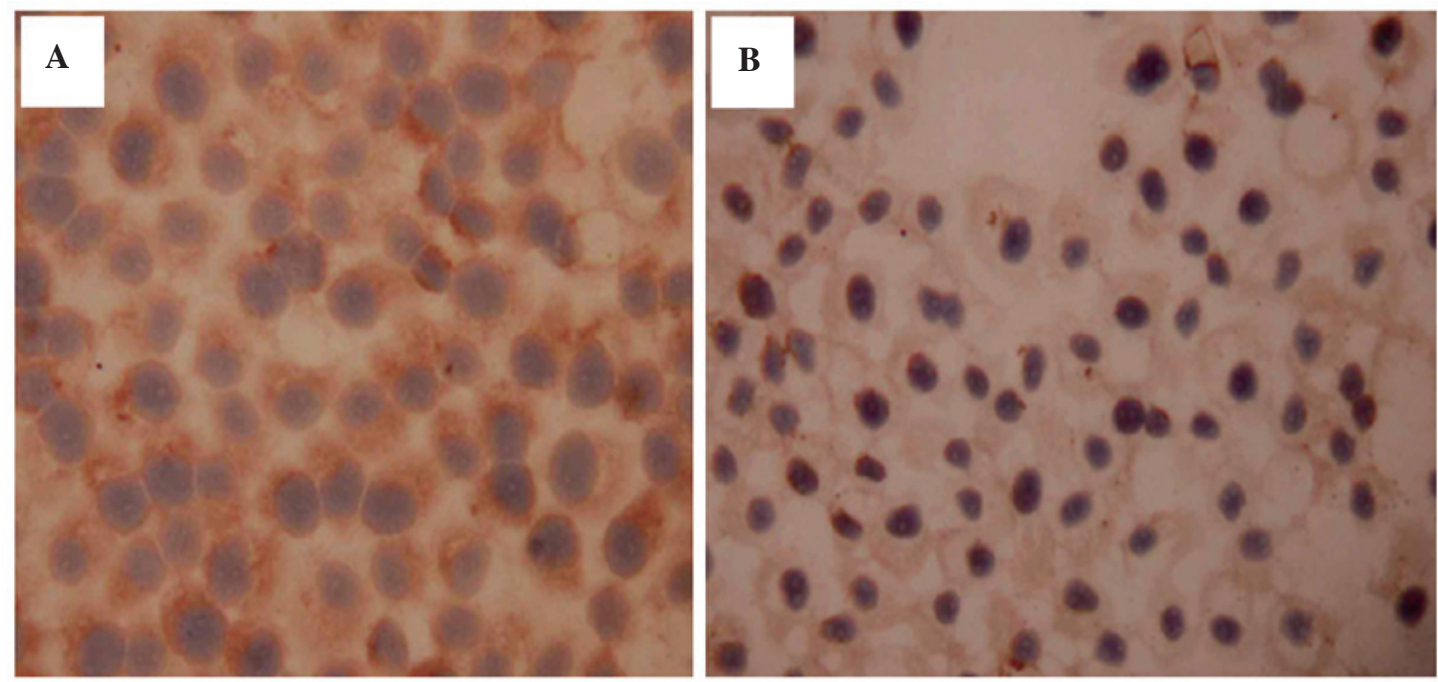

Figure 2. Immunohistochemistry of Ras protein in (A) SGC7901/ADM cells (Ras predominantly localized in the membrane and partially translocated in the cytoplasm) and (B) SGC7901/ADM cells treated with $0.5 \mu \mathrm{M} \mathrm{As}_{2} \mathrm{O}_{3}$ for $48 \mathrm{~h}$ (Ras protein expression observed to be reduced) (magnification, $\mathrm{x}^{400)}$. As $\mathrm{O}_{2}$, arsenic trioxide.

Ras/p-ERK1/2 signaling pathway is involved in reducing drug resistance. The cells were incubated with non- and mildly-toxic concentrations of $\mathrm{As}_{2} \mathrm{O}_{3}$ for $48 \mathrm{~h}$ and, following pretreatment with rhG-CSF, cytokines activating the ERK pathway, Ras and p-ERK1/2 were assessed using immunocytochemistry.

Following rhG-CSF treatment, the expression of Ras was similar in all groups $(\mathrm{P}>0.05)$. No difference was identified in the levels of Ras between the SGC7901/ADM and CsA-treated cells ( $\mathrm{P}>0.05$; Table IV; Fig. 4A and B). Compared with the cells without rhG-CSF treatment, the levels of Ras were not different $(\mathrm{P}=0.12)$ in the $0.1 \mu \mathrm{M} \mathrm{As}_{2} \mathrm{O}_{3}$-treated groups, but were higher in the $\mathrm{As}_{2} \mathrm{O}_{3} 0.5 \mu \mathrm{M} \mathrm{As}_{2} \mathrm{O}_{3}$-treated groups $(\mathrm{P}<0.01)$.

The levels of $\mathrm{p}$-ERK1/2 in all the cells increased following rhG-CSF treatment (Table IV; $\mathrm{P}<0.01$ ). Treatment with 0.10 and 
Table IV. Protein expression levels of Ras and p-ERK1/2 with or without treatment of rhG-CSF, determined using immunocytochemistry (optical density).

\begin{tabular}{|c|c|c|c|}
\hline Protein & Treatment & rhG-CSF/- & rhG-CSF/+ \\
\hline \multirow[t]{4}{*}{ Ras b } & $\mathrm{As}_{2} \mathrm{O}_{3}(0.1 \mu \mathrm{M})^{\mathrm{b}}$ & $0.084 \pm 0.001$ & $0.093 \pm 0.008$ \\
\hline & $\mathrm{As}_{2} \mathrm{O}_{3}(0.5 \mu \mathrm{M})$ & $0.078 \pm 0.003$ & $0.089 \pm 0.001$ \\
\hline & $\mathrm{CsA}(4 \mu \mathrm{g} / \mathrm{ml})$ & $0.093 \pm 0.003$ & $0.099 \pm 0.005$ \\
\hline & SGC7901/ADM & $0.094 \pm 0.006$ & $0.10 \pm 0.008$ \\
\hline \multirow[t]{4}{*}{$\mathrm{p}-\mathrm{ERK} 1 / 2^{\mathrm{a}}$} & $\mathrm{As}_{2} \mathrm{O}_{3}(0.1 \mu \mathrm{M})$ & $0.086 \pm 0.002$ & $0.093 \pm 0.002$ \\
\hline & $\mathrm{As}_{2} \mathrm{O}_{3}(0.5 \mu \mathrm{M})$ & $0.080 \pm 0.002$ & $0.091 \pm 0.001$ \\
\hline & $\mathrm{CsA}(4 \mu \mathrm{g} / \mathrm{ml})$ & $0.11 \pm 0.018$ & $0.12 \pm 0.019$ \\
\hline & SGC7901/ADM & $0.10 \pm 0.010$ & $0.14 \pm 0.003$ \\
\hline
\end{tabular}

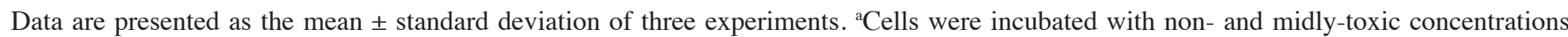
of $\mathrm{As}_{2} \mathrm{O}_{3} \cdot{ }^{\mathrm{b}} \mathrm{Compared}$ with cells without rhG-CSF, the levels of Ras levels not significantly different $(\mathrm{P}=0.12)$ in the $\mathrm{As}_{2} \mathrm{O}_{3}(0.1 \mu \mathrm{M}) \mathrm{groups}$

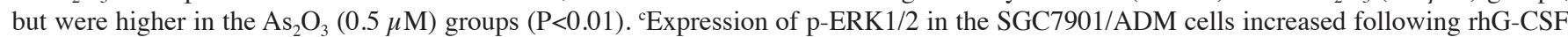
treatment $(\mathrm{P}<0.01) . \mathrm{As}_{2} \mathrm{O}_{3}$, arsenic trioxide; rhG-CSF, recombinant human granulocyte colony stimulating factor; p-ERK, phosphorylated extracellular signal-regulated kinase; CsA, cyclosporin A.
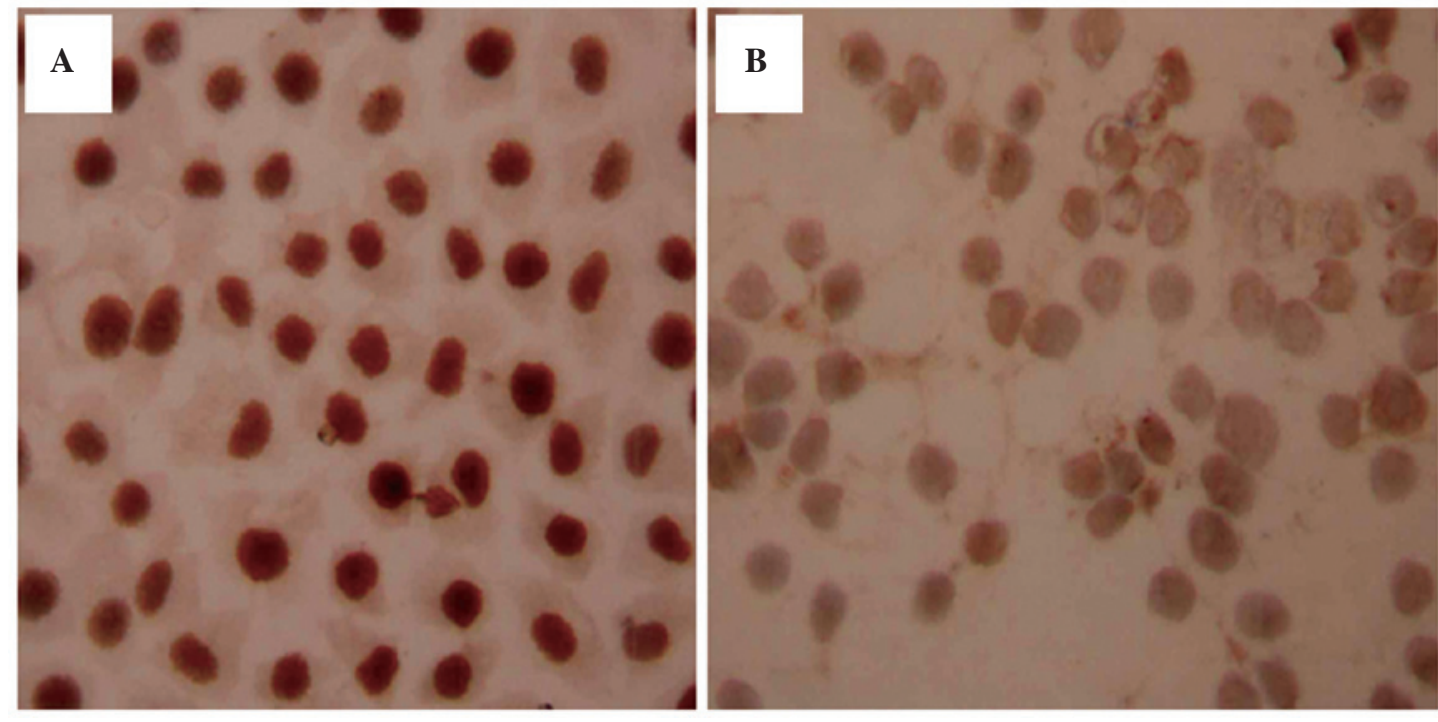

Figure 3. Immunohistochemistry of (A) p-ERK1/2 protein in the SGC7901/ADM cells and (B) SGC7901/ADM cells treated with $0.5 \mu \mathrm{M}$ As $\mathrm{O}_{3}$ for $48 \mathrm{~h}$ (magnification, $\mathrm{x} 400$ ). Expression of p-ERK1/2 was detected in the cytoplasm surrounding the nucleus of the cells. p-ERK, phosphorylated-extracellular signal-regulated kinase; $\mathrm{As}_{2} \mathrm{O}_{3}$, arsenic trioxide.

$0.50 \mu \mathrm{M} \mathrm{As}_{2} \mathrm{O}_{3}$ reduced the levels of p-ERK1/2, compared with the negative control group $(\mathrm{P}<0.05$; Fig. $5 \mathrm{~A}$ and $\mathrm{B})$, whereas the levels of p-ERK1/2 increased significantly at the same doses of $\mathrm{As}_{2} \mathrm{O}_{3}$ following rhF-CSF treatment $(\mathrm{P}<0.01)$. Similar to Ras, these results suggested that the expression of p-ERK1/2 decreased following treatment with the ERK activator.

\section{Discussion}

GC is one of the most common types of cancer, and generally has a poor prognosis. DOX is used as one of the key components in a number of chemotherapeutic regimens against GC, however, MDR eventually limits its use. Several types of cancer cell, including non-acute myeloid leukemia, multiple myeloma, breast cancer and APL, have been found to be sensitive to $\mathrm{As}_{2} \mathrm{O}_{3}$ through cell growth inhibition and apoptosis $(12,20,28,29)$. However, few studies have examined the effects of $\mathrm{As}_{2} \mathrm{O}_{3}$ in $\mathrm{GC}$ cells, and these studies reported a number of different mechanisms (30-32). In the present study, the human GC cell lines, SGC7901/S and SGC7901/ADM, were investigated. The latter was induced by long-term continuous exposure to DOX in a step-wise increment of various concentrations. The high $\mathrm{IC}_{50}$ of SGC7901/ADM, but not of SGC7901/S, confirmed the resistance to DOX. The doses of 0.10 and $0.50 \mu \mathrm{M}$ of $\mathrm{As}_{2} \mathrm{O}_{3}$ were defined as non- and mildly-toxic concentrations, respectively. This was different from the study by Zhao et al (22), which reported that $2 \mu \mathrm{M}$ was the non-toxic concentration. In the MTT assay for the detection of cytotoxicity and sensitivity to $\mathrm{As}_{2} \mathrm{O}_{3}$, cell growth was inhibited without any treatment at $72 \mathrm{~h}$. This was possibly 

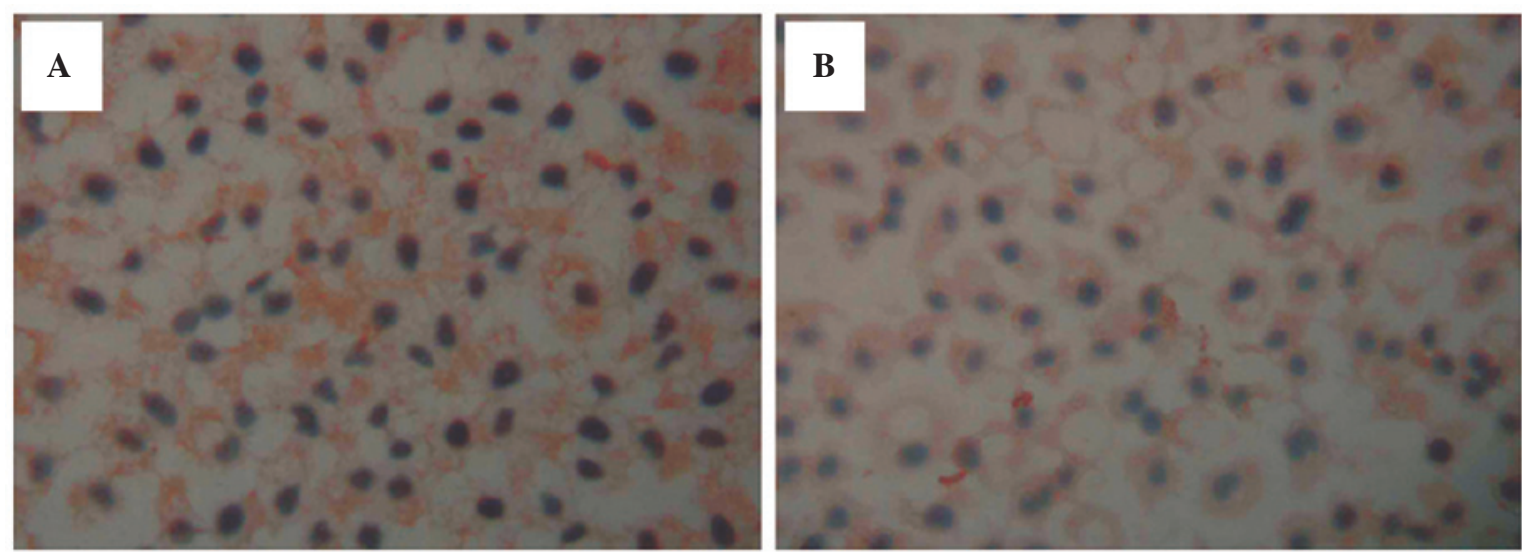

Figure 4. Immunohistochemistry of (A) Ras protein in the SGC7901/ADM cells following treatment with $0.1 \mu \mathrm{M} \mathrm{As}_{2} \mathrm{O}_{3}$ and rhG-CSF for $48 \mathrm{~h}$. (B) Ras protein in the SGC7901/ADM cells following treatment with $0.5 \mu \mathrm{M} \mathrm{As}_{2} \mathrm{O}_{3}$ and rhG-CSF for $48 \mathrm{~h}$ (magnification, $\mathrm{x} 400$ ). No differences were identified in the levels of Ras between the SGC7901/ADM- and CsA-treated cells. Compared with the cells without rhG CSF treatment, the levels of Ras were not significantly different $(\mathrm{P}=0.12)$ in the $0.1 \mu \mathrm{M} \mathrm{As}_{2} \mathrm{O}_{3}$-treated groups, however were greater in the $0.5 \mu \mathrm{M} \mathrm{As}_{2} \mathrm{O}_{3}$-treated groups $(\mathrm{P}<0.01)$. rhG-CSF, recombinant human granulocyte colony stimulating factor; $\mathrm{As}_{2} \mathrm{O}_{3}$, arsenic trioxide.
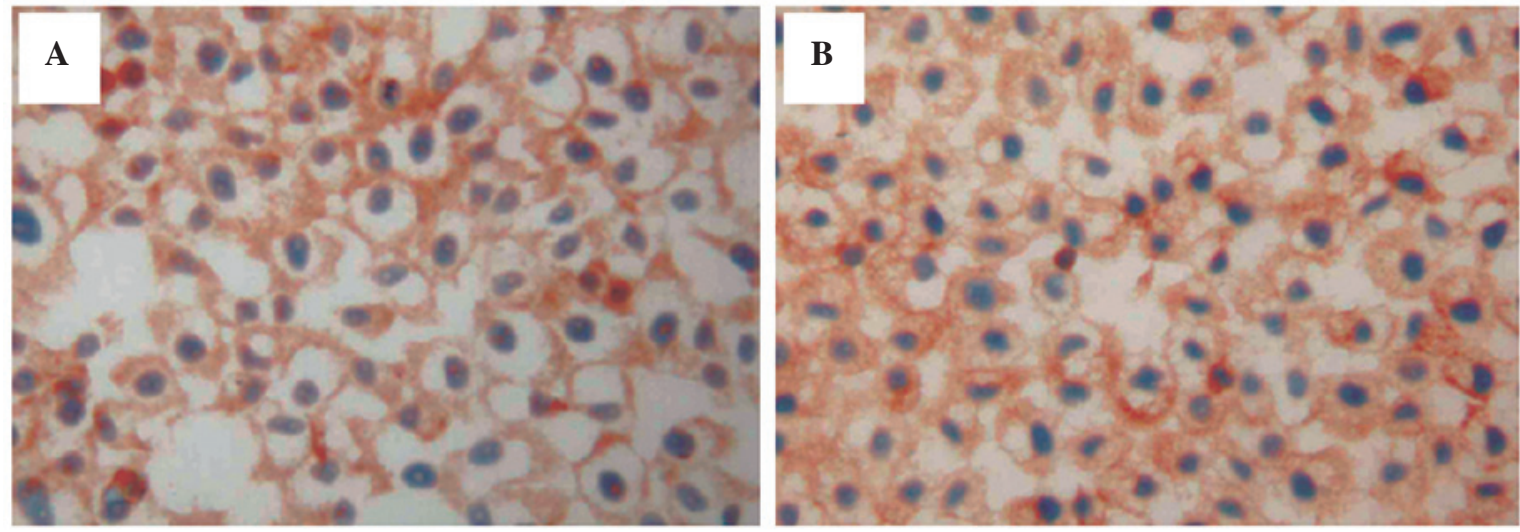

Figure 5. Immunohistochemistry of (A) p-ERK1/2 protein in the SGC7901/ADM cells following treatment with $\mathrm{As}_{2} \mathrm{O}_{3}(0.1 \mu \mathrm{M})$ and rhG-CSF for 48 h; (B) p-ERK1/2 protein in the SGC7901/ADM cells following treatment with $0.5 \mu \mathrm{M} \mathrm{As}_{2} \mathrm{O}_{3}$ and rhG-CSF for $48 \mathrm{~h}$ (magnification, $\mathrm{x} 400$ ). Treatment with 0.10 and $0.50 \mu \mathrm{M} \mathrm{As}_{2} \mathrm{O}_{3}$ reduced the levels of p-ERK1/2, compared with the negative control group. p-ERK, phosphorylated extracellular signal-regulated kinase; rhG-CSF, recombinant human granulocyte colony stimulating factor; $\mathrm{As}_{2} \mathrm{O}_{3}$, arsenic trioxide.

the result of the toxic metabolic accumulation and nutrient deficiency. Previously, it was found that $\mathrm{As}_{2} \mathrm{O}_{3}$ induced APL cells to enter apoptosis (6). The present study demonstrated that $\mathrm{As}_{2} \mathrm{O}_{3}$ partially reduced in vitro drug-resistance, even at a non-toxic dose $(0.10 \mu \mathrm{M})$, in a time- and dose-dependent manner.

A number of mechanisms are involved in MDR, and the ovexpression of P-gp is one of the key mechanisms. Agents to reduce MDR have been investigated for a number of years $(33,34)$. A novel inhibitor of P-gp-mediated MDR, OC144-093, was reported in 2000 (28). In the present study, the expression of P-gp in SGC7901/ADM was higher than in the parental cells and, following $\mathrm{As}_{2} \mathrm{O}_{3}$ treatment, the levels of P-gp decreased significantly. The non- and mildly-toxic doses of $\mathrm{As}_{2} \mathrm{O}_{3}$ were selected with the purpose of using them in clinical practice without serious side effects.

Several studies have reported the in vitro effects of $\mathrm{As}_{2} \mathrm{O}_{3}$ in the inhibition of different types of solid tumor, through a number of different mechanisms. Eguchi et al (19) demonstrated that apoptosis induced in human mesothelioma cells is accompanied by the activation of JNK1/2 and ERK1/2 (19). In breast cancer, $\mathrm{As}_{2} \mathrm{O}_{3}$ inhibits cell growth through the inactivation of the Notch signaling pathway (20). To investigate the role of the Ras/p-ERK1/2 signaling pathway in the mechanism of $\mathrm{As}_{2} \mathrm{O}_{3}$, the rhG-CSF cytokine, which activates the ERK pathway was used to treat the cells.

Ras is a monomeric GTP-coupled protein encoded by the Ras gene, which is important in cell growth regulation (35). It was reported in 1993 that Ras has direct interactions with the RAF1 serine/threonine kinase, which was the first mammalian Ras effector to be identified (36). ERK1 and ERK2, also termed mitogen-activated protein kinase (MAPK) 1 and MAPK2 are MAPK isomers, which are widely expressed in eukaryotic cells. In addition, the identification of B-Raf mutations in cancer emphasize the importance for aberrant Raf-MEK-ERK signaling in oncogenesis (36). In the present study, the levels of Ras and p-ERK were determined using immunocytochemistry. The levels of Ras were higher in the SGC7901/ADM cells than in the SGC7901/S cells, however, no significant difference was observed in the levels of p-ERK1/2. The results suggested that p-ERK1/2 was not involved in the MDR mechanisms in these cells, but indicated that Ras was 
involved. Following treatment with $\mathrm{As}_{2} \mathrm{O}_{3}$, the levels of Ras levels reduced, and the protein levels of p-ERK1/2 decreased until intervention with mildly-toxic concentrations of $\mathrm{As}_{2} \mathrm{O}_{3}$ $(0.50$ and $0.75 \mu \mathrm{M})$.

Following pretreatment with rhG-CSF, no change was observed in the levels of Ras in cells from the control groups, however, levels increased in the $0.50 \mu \mathrm{M} \mathrm{As}_{2} \mathrm{O}_{3}$ treatment group. The expression of p-ERK1/2 increased in all cells, suggesting that rhG-CSF activated $\mathrm{p}-\mathrm{ERK} 1 / 2 . \mathrm{As}_{2} \mathrm{O}_{3}$ reduced the levels of p-ERK1/2, compared with the negative control group. Thus, a p-ERK activator may partially inhibit the drug resistance-reversing effects of $\mathrm{As}_{2} \mathrm{O}_{3}$. A phase II trial revealed that $\mathrm{As}_{2} \mathrm{O}_{3}$ is inactive in patients with pancreatic cancer, who develop a progressive disease following gemcitabine treatment (37). This failure may be due to the lack of co-treatment with other chemotherapeutics. $\mathrm{As}_{2} \mathrm{O}_{3}$ has been demonstrated to be effective in treating APL without significant side effects $(8,9)$.

The present study involved the examination of MDR induced by DOX. There are several other chemotherapeutic agents, which are actively used in the treatment of GC in a number of combination regimens (38). Further investigations are required to examine the effect of $\mathrm{As}_{2} \mathrm{O}_{3}$ in reversing the MDR induced by these other agents. In addition, it is important to further investigate the effects of $\mathrm{As}_{2} \mathrm{O}_{3}$ in $\mathrm{GC}$, compared with other types of cancer. Although the present study clearly suggested the involvement of Ras in the MDR of GC, further investigations are required to clarify whether mutations in Raf are involved in drug-resistant cells. Finally, the rhG-CSF cytokine, used in the present study to activate the ERK pathway, also activates a number of other cell mechanisms, which require further investigations, including the PI3K/AKT pathway $(39,40)$.

In conclusion, the results of the present study revealed that $\mathrm{As}_{2} \mathrm{O}_{3}$ had the ability to reverse MDR in human GC cells. This mechanism may be relevant to reduce the expression of P-gp. Drug-resistant cells may have higher expression levels of Ras, and $\mathrm{As}_{2} \mathrm{O}_{3}$ may decrease these levels. The Ras/p-ERK1/2 signal transduction pathway may be involved in this mechanism. Further investigations, involving a combination of chemotherapeutics and arsenic trioxide, are essential.

\section{Acknowledgements}

This study was supported by ths Qingdao Municipal Science and Technology Commission (grant no. 09-1-3-75-jch). The authors would like to thank Dr Jing Dong for his critical reading of the manuscript, and the Central Laboratory of the Affiliated Hospital of the Medical College Qingdao University for providing cell lines.

\section{References}

1. Ferlay J, Shin HR, Bray F, Forman D, Mathers C and Parkin DM: Estimates of worldwide burden of cancer in 2008: GLOBOCAN 2008. Int J Cancer 127: 2893-2917, 2010.

2. Matsuda A and Machii R: Trends in stomach cancer mortality rates in Japan, USA, UK, France and Korea based on the WHO mortality database. Jpn J Clin Oncol 42: 154, 2012.

3. Parkin DM, Bray F, Ferlay J and Pisani P: Global cancer statistics, 2002. CA Cancer J Clin 55: 74-108, 2005.
4. Zheng LH, Bao YL, Wu Y, Yu CL, Meng X and Li YX: Cantharidin reverses multidrug resistance of human hepatoma HepG2/ADM cells via down-regulation of P-glycoprotein expression. Cancer Lett 272: 102-109, 2008.

5. Volm M and Mattern J: Resistance mechanisms and their regulation in lung cancer. Crit Rev Oncog 7: 227-244, 1996.

6. Mervis J: Ancient remedy performs new tricks. Science 273: 578 , 1996.

7. Zhu J, Chen Z, Lallemand-Breitenbach V and de Thé H: How acute promyelocytic leukaemia revived arsenic. Nat Rev Cancer 2: 705-713, 2002.

8. Zhang TD, Chen GQ, Wang ZG, Wang ZY, Chen SJ and Chen Z: Arsenic trioxide, a therapeutic agent for APL. Oncogene 20: 7146-7153, 2001

9. Lo-Coco F, Avvisati G, Vignetti M, Thiede C, Orlando SM, Iacobelli S, Ferrara F, Fazi P, Cicconi L, Di Bona E, et al: Retinoic acid and arsenic trioxide for acute promyelocytic leukemia. N Engl J Med 369: 111-121, 2013.

10. Murgo AJ: Clinical trials of arsenic trioxide in hematologic and solid tumors: Overview of the National Cancer Institute Cooperative Research and Development Studies. Oncologist 6 (Suppl 2): 22-28, 2001.

11. Lu J, Chew EH and Holmgren A: Targeting thioredoxin reductase is a basis for cancer therapy by arsenic trioxide. Proc Natl Acad Sci USA 104: 12288-12293, 2007.

12. Munshi NC: Arsenic trioxide: An emerging therapy for multiple myeloma. Oncologist (6 Suppl 2): 17-21, 2001.

13. Maeda H, Hori S, Nishitoh H, Ichijo H, Ogawa O, Kakehi Y and Kakizuka A: Tumor growth inhibition by arsenic trioxide (As2O3) in the orthotopic metastasis model of androgen-independent prostate cancer. Cancer Res 61: 5432-5440, 2001.

14. Shen ZY, Zhang Y, Chen JY, Chen MH, Shen J, Luo WH and Zeng Y: Intratumoral injection of arsenic to enhance antitumor efficacy in human esophageal carcinoma cell xenografts. Oncol Rep 11: 155-159, 2004.

15. Bornstein J, Sagi S, Haj A, Harroch J and Fares F: Arsenic Trioxide inhibits the growth of human ovarian carcinoma cell line. Gynecol Oncol 99: 726-729, 2005.

16. Woo SH, Park IC, Park MJ, Lee HC, Lee SJ, Chun YJ, Lee SH, Hong SI and Rhee CH: Arsenic trioxide induces apoptosis through a reactive oxygen species-dependent pathway and loss of mitochondrial membrane potential in HeLa cells. Int $\mathrm{J}$ Oncol 21: 57-63, 2002.

17. Miller WH Jr, Schipper HM, Lee JS, Singer J and Waxman S: Mechanisms of action of arsenic trioxide. Cancer Res 62: 3893-3903, 2002.

18. Pelicano H, Feng L, Zhou Y, Carew JS, Hileman EO, Plunkett W, Keating MJ and Huang P: Inhibition of mitochondrial respiration: a novel strategy to enhance drug-induced apoptosis in human leukemia cells by a reactive oxygen species-mediated mechanism. J Biol Chem 278: 37832-37839, 2003.

19. Eguchi R, Fujimori Y, Takeda H, Tabata C, Ohta T, Kuribayashi K, Fukuoka $\mathrm{K}$ and Nakano T: Arsenic trioxide induces apoptosis through JNK and ERK in human mesothelioma cells. J Cell Physiol 226: 762-768, 2011.

20. Xia J, Li Y, Yang Q, Mei C, Chen Z, Bao B, Ahmad A, Miele L, Sarkar FH and Wang Z: Arsenic trioxide inhibits cell growth and induces apoptosis through inactivation of notch signaling pathway in breast cancer. Int J Mol Sci 13: 9627-9641, 2012.

21. Xiao Z, Ding N, Xiao G, Wang S, Wu Y and Tang L: Reversal of multidrug resistance by gefitinib via RAF1/ERK pathway in pancreatic cancer cell line. Anat Rec (Hoboken) 295: 2122-2128, 2012.

22. Zhao D, Jiang Y, Dong X, Liu Z, Qu B, Zhang Y, Ma N and Han Q: Arsenic trioxide reduces drug resistance to adriamycin in leukemic K562/A02 cells via multiple mechanisms. Biomed Pharmacother 65: 354-358, 2011.

23. Zhao Y, You H, Liu F, An H, Shi Y, Yu Q and Fan D: Differentially expressed gene profiles between multidrug resistant gastric adenocarcinoma cells and their parental cells. Cancer Lett 185: 211-218, 2002.

24. Che XF, Nakajima Y, Sumizawa T, Ikeda R, Ren XQ, Zheng CL, Mukai M, Furukawa T, Haraguchi M, Gao H, et al: Reversal of P-glycoprotein mediated multidrug resistance by a newly synthesized 1,4-benzothiazipine derivative, JTV-519. Cancer Lett 187: 111-119, 2002.

25. Wang R, Xia L, Gabrilove J, Waxman S and Jing Y: Downregulation of Mcl-1 through GSK-3 $\beta$ activation contributes to arsenic trioxide-induced apoptosis in acute myeloid leukemia cells. Leukemia 27: 315-324, 2013. 
26. Brandstetter T, Ninci E, Falken U, Wagner E, Hess $R$ and Bauknecht T: rhG-CSF affects genes involved in mitogen signalling and early gene expression in the ovarian cancer cell line HEY. Int J Cancer 75: 847-854, 1998.

27. Ricciardi MR, McQueen T, Chism D, Milella M, Estey E, Kaldjian E, Sebolt-Leopold J, Konopleva M and Andreeff M: Quantitative single cell determination of ERK phosphorylation and regulation in relapsed and refractory primary acute myeloid leukemia. Leukemia 19: 1543-1549, 2005.

28. Newman MJ, Rodarte JC, Benbatoul KD, Romano SJ, Zhang C, Krane S, Moran EJ, Uyeda RT, Dixon R, Guns ES, et al: Discovery and characterization of OC144-093, a novel inhibitor of P-glycoprotein-mediated multidrug resistance. Cancer Res 60 : 2964-2972, 2000.

29. Li Y, Qu X, Qu J, Zhang Y, Liu J, Teng Y, Hu X, Hou K and Liu Y: Arsenic trioxide induces apoptosis and G2/M phase arrest by inducing $\mathrm{Cbl}$ to inhibit PI3K/Akt signaling and thereby regulate p53 activation. Cancer Lett 284: 208-215, 2009.

30. Chen X, Zhang M and Liu LX: The overexpression of multidrug resistance-associated proteins and gankyrin contribute to arsenic trioxide resistance in liver and gastric cancer cells. Oncol Rep 22: 73-80, 2009.

31. Liu Y, Zhang W, Zhang X, Qi Y, Huang D and Zhang Y: Arsenic trioxide inhibits invasion/migration in SGC-7901 cells by activating the reactive oxygen species-dependent cyclooxygenase-2/matrix metalloproteinase-2 pathway. Exp Biol Med (Maywood) 236: 592-597, 2011.

32. Zhang G, Liu J, Zhang Y, Qu J, Xu L, Zheng H, Liu Y and Qu X: Cbl-b-dependent degradation of FLIP(L) is involved in ATO-induced autophagy in leukemic K562 and gastric cancer cells. FEBS Lett 586: 3104-3110, 2012.
33. Baguley BC: Multiple drug resistance mechanisms in cancer. Mol Biotechnol 46: 308-316, 2010.

34. Gillet JP and Gottesman MM: Mechanisms of multidrug resistance in cancer. Methods Mol Biol 596: 47-76, 2010.

35. Wong KA, Russo A, Wang X, Chen YJ, Lavie A and O'Bryan JP: A new dimension to Ras function: A novel role for nucleotide-free Ras in Class II phosphatidylinositol 3-kinase beta (PI3KC2 $\beta$ ) regulation. PLoS One 7: e45360, 2012.

36. Karnoub AE and Weinberg RA: Ras oncogenes: Split personalities. Nat Rev Mol Cell Biol 9: 517-531, 2008

37. Kindler HL, Aklilu M, Nattam S and Vokes EE: Arsenic trioxide in patients with adenocarcinoma of the pancreas refractory to gemcitabine: A phase II trial of the University of Chicago Phase II Consortium. Am J Clin Oncol 31: 553-556, 2008.

38. NCCN Clinical Practice Guidelines in Oncology (NCCN Guidelines): Gastric Cancer. 3rd edition. National Comprehensive Cancer Network, Fort Washington, 2015.

39. Guo H, Sun F, Huang W, Liu Z, Zhang S, Zhou Q and Liang C: The effect of rhG-CSF on spleen transcriptome in mouse leukopenia model induced by cyclophosphamide. Immunopharmacol Immunotoxicol 36: 114-123, 2014.

40. Kumar J, Fraser FW, Riley C, Ahmed N, McCulloch DR and Ward AC: Granulocyte colony-stimulating factor receptor signalling via Janus kinase 2/signal transducer and activator of transcription 3 in ovarian cancer. Br J Cancer 110: 133-145, 2014. 